\title{
The Reflection of Love for Motherland in the Select Poems of Agha Shahid Ali
}

\author{
Firdous Ahmad Dar (MA MPhil Pursuing Ph.D.) \\ Research Scholar DAVV Indore
}

\begin{abstract}
Agha Shahid Ali the famous poet and many of his themes are rotating around the Kashmir valley and it social conditions, the conditions which were unpredictable in the 1990s, in his poetry he likewise grieves appears to be grieving for being a long way from his home (Kashmir). Shahid Ali has his own dejection of being a diasporic artist and living at a place that never frequented him for an amazing duration that is his country Kashmir. He is extremely remorseful for losing his mother and this anguish is prowled in his poetry, which sooth his readers of the same misery and turns into an all-inclusive message. What Shahid Ali is discussing, is the quality or condition of monitoring an outside thing or something inside oneself. It has been characterized as consciousness, mindfulness, subjectivity, the capacity to encounter or to feel, attentiveness, having a feeling of selfhood, and the official control arrangement of the brain.
\end{abstract}

Keywords: Dejection, diasporic, anguish, consciousness, grieves, Shahid Ali

DOI: $10.7176 /$ JLLL/53-06

\section{Introduction}

Agha Shahid Ali was born in New Delhi on February 4, 1949, and experienced childhood in Kashmir. He spent his adolescence in Kashmir, and in the wake of finishing his studies from Presentation Convent School, Burn Hall School and the University of Kashmir he moved to Delhi to do his post-graduation from Hindu College where he instructed too. From that point he moved, to the U.S.A. He was granted a Ph.D. degree in English from Pennsylvania State University in 1984 and an M.F.A. from the University of Arizona in 1985.

Moving to start with one place then onto the next, and having born and brought up in various societies and social orders, Shahid had the effect of different societies on his personality. He had Muslim, Hindu and Kashmiri culture, and was exposed to the Indian culture and convention. He was very much familiar with Western culture as well, as the family spends a couple of years there, during Shahid's adolescence. The different societies he was presented to, and different individuals he went over impacted him. Among them are his mom well-known ghazal vocalist Begum Akhtar and his lifelong friend James Merrill. Aside from these, he cherished ghazals of Mirza Ghalib, particularly those that were sung by Begum Akhtar. He grew up in a home where individuals examined about legends from different fields and societies since they used to talk about Urdu artists like Ghalib and Faiz, Mir and Hafiz, philosophers like Aristotle and Plato, about English artists like Shakespeare and Keats, legends like Laila-Majnoon and Heer-Ranjha. Being tolerant the family watched Muharram, observed Diwali and Shabe-baraat, Christmas and so on with incredible energy which helped him to establish a framework that discovers articulation in a portion of Shahid's ballads. Shahid talks about Laila-Majnoon and Heer-Ranjha, Muharram and the legends related with it, Zainab(s) and Imam Hussain(a) and the deplorable place that is known for Karbala. Shahid expounds on Krishna, Shiva's trident, Parvati's anklet, about Radha and numerous such characters. The renowned works of Agha Shahid Ali incorporate:

The Country without Post- office (1997), Rooms are Never Finished (2001), Call me Ishmael Tonight, The Half-Inch Himalayas (1987), The veiled Suit: The Collected Poems (2009), A Nostalgist's Map of America (1991), A Walk Through Yellow Pages (1987).

Shahid Ali's poetry appears to mirror the view that how poetry, without decreasing its masterful core, can be a mechanism of protection from a challenge the distorted truth of onerous power structures in the contemporary world. Shahid's poetry subsequently can be viewed as both approximating and rethinking the convention he acquired as a Kashmiri artist. There has been an exceptional impact of Agha Shahid among the ongoing age of Kashmiri-English writers both fiction and nonfiction authors. Indeed, even Kashmiri and Urdu scholars are bearing his impact. Not just scholars, we are likewise seeing painters, sketch artists, calligraphers, artists, and so forth utilizing their individual imaginative mediums to offer voice to their stifled yearnings desensitized by the viciousness and mistreatment.

Kashmiriyat, as a cultural identity, was given essence through the Sufi-mystic tradition through successive ages, but it also seems that Kashmiriyat as a standard analytical tool in studying the cultural politics of Kashmir has been rather too gaudy which provides a thick facade to serious political manipulations. Chitralekha Zutshi locates and interrogates Kashmiriyat as a historical entity, asserting that Kashmiri regional identities have been far more ambiguous, and certainly more complex than the term Kashmiriyat would lead one to assume. Zutshi argues:

To suggest that a Kashmiri identity, Kashmiriyat, defined as a harmonious blending of religious 
cultures has somehow remained unchanged and an integral part of Kashmiri history over the centuries is a historical fallacy. Certainly, Kashmiri identities have followed a distinct trajectory depending on a host of factors, including state and economic structures, political culture, and the religious milieu at particular historical moments.

His work spoke about the desire he felt for home. His work reflects the longing wish to see peace returning to Kashmir. The poem, Postcard from Kashmir, is the reflection of his love for his motherland. "Kashmir shrinks into my mailbox, My home a neat four by six inches. This is home. And this closest, I'll ever be to home. When I return, the colours won't be so brilliant, the Jhelum's waters so clean, so ultramarine. My love so overexposed."

In The Country Without a Post Office, the country that Ali is referring to is Kashmir which is seen as a post office of an archive for letters with doomed addresses. The very title of the anthology is suggestive of the complete and all-pervasive sense of loss for the poet. There was a time when Kashmir was called as the paradise on earth and now due to uprising every family directly or indirectly has been affected by the conditions that are prevailing there for the past twenty years. He has written about the young boys who lost their lives and how they were tortured either by the militants or by defense authorities. In the poem entitled I See Kashmir from New Delhi at Midnight, he writes: Drippings from a suspended burning tire, are falling on the back of a prisoner, the naked boy screaming, "I know nothing."

In Kashmir, many families have lost their only sons and have become sonless But Ali is still hopeful that the conditions in Kashmir will become normal one day. In the same poem in the end, he writes, "I've tied a knot, with green thread at Shah Hamdan, to be, united only when the atrocities, are stunned by your jeweled return." Shah Hamadan is a shrine in Kashmir where both Hindus and Muslims tie knots with green thread. It is a kind of ritual, which is supposed to bring peace and love between the two communities. Although Ali writes about loss, but he is a poet with hope somewhere. In all his writings, he ends on a positive note. He is hopeful that one day everything will be normal. In the poem, Dear Shahid, which is in the form of the letter, describes the condition and feeling of insecurity the people go through every day in Kashmir. He writes that every person who leaves his home "carries his address in his pocket so that at least his body will reach home." However, this does not mean that Ali has lost all hope. He is hopeful that the day will come when everybody will be united and conditions will become normal. He is still sure that the will come when all the fractions will be peacefully reconciled. He writes, And, if God wills, O! those days of peace when we all were in love and the rain was in our hands wherever we went." Agha Shahid is waiting with utter anxiety to reach back to his homeland Kashmir, he is waiting like a Sufi, like Majnoon. He is much desperate for the reunion of him and his Kashmir. The pains of exile remain salad in which he has the only cure that is the reunion. Ali's poetry is infused with anguish about his lost culture and its turmoil.

\section{Conclusion}

Given all this relativism, Sufism, however, as a way of living, has had an influence on the whole gamut of Islamic culture, art, architecture, and literature. This influence is apparent on most of the Muslim writers through the ages. The literature produced by the Sufis like Rumi, Attar, and Jami has influenced even the secular literature overages. Masood-ulHasan's book Sufism and English Literature Chaucer to the Present Age: Echoes and Images give a detailed account of the influence of Sufism on English Literature beginning from Chaucer to the present day, covering writers like Salman Rushdie and Doris Lessing. The meeting of the West and Islam began with early trade followed by the conquest of Spain and the crusades. This meeting carried some knowledge and stories from the Muslim world to the West. Agha Shahid and his poetry are fully inundated with these explicated and implicated influences, his childhood had passed under the atmosphere where there are Sufi talks in the day to day expressions of people. The valley of Kashmir as we know is also called Reshi-Wari, which means land of Sufi's. So his poetry echoes with Sufism(Mysticism). There is also a tremendous effect and influence of Urdu poetry (language) there; this is another reason that Mr. Ali was in deep inclination and linkage to the poets and thinkers whose concern was with pristine spirituality.

\section{Bibliography}

Alexander, Meena.Composing Poetry: Poetry of the Indian Diaspora.Spec. issue of KavyaBharti.2004. Print.

Ali, Agha Shahid. A Nostalgist's Map of America:Poems. New York: Norton, 1991. Print

---. A Walk Through the Yellow Pages. Tucson: SUN-gemini, 1987. Print.

---. Ravishing Disunities:Real Ghazals in English.Middletown: Wesleyan UP, 2000. Print

---.Rooms Are Never Finished:Poems. New York: Norton, 2002. Print.

---. The Country without a Post Office. New York, U.S: W.W. Norton \&Company, 1997. Print

---. The Half-Inch Himalayas. Middletown: Wesleyan UP, 1987.Print.

---. The Veiled Suite: The Collected Poems. New Delhi: Penguin, 2010. Print.

Zutshi, Chitralekha. Languages of Belonging: Islam, Regional Identity, and the Making of Kashmir. New Delhi: Permanent Black, 2002. Print 